ВОЛКОВA С. В., MAPKOB Б. В. EDUCATION DILEMMAS IN THE DIGITAL ERA: PHILOSOPHICAL APPROACH // StUdia Humanitatis Borealis. 2020. № 3. C. 9-16.

научный электронный журнал

ПЕТРОЗАВОАСКИЙ ГОСУААРСТВЕННЫЙ Studia Humanitatis Borealis УНИВЕРСИТЕТ

https://sthb.petrsu.ru

http://petrsu.ru

УдК 37.017.7 + 37.017.922

\title{
EDUCATION DILEMMAS IN THE DIGITAL ERA: PHILOSOPHICAL APPROACH
}

\author{
ВОЛКОВА \\ Светлана \\ Владимировна
}

\author{
доктор философских наук, \\ профрессор кафедры философии и культурологии, \\ Петрозаводский государственный университет, \\ кафедра философии и культурологии, \\ Петрозаводск, Российская Федерация, \\ svetavolkov@ya.ru \\ доктор философских наук, \\ профессор кафедры философской антропологии, \\ Санкт-Петербургский государственный университет, \\ Институт философии, кафедра философской \\ антропологии, \\ Санкт-Петербург, Российская Федерация, \\ bmarkov@mail.ru
}

(c) 2020 Петрозаводский государственный университет

\section{EDUCATION DILEMMAS IN THE DIGITAL ERA: PHILOSOPHICAL APPROACH}

\section{Introduction. Problem and Purpose}

Modernization of universities requires reflection on the phenomenon of education. Today, education has become a competitive enterprise. Students have to compete for scarce places in universities. Universities compete for status and ranking, and generally for funding. Thus, whoever has the highest rate wins. This applies both to educators and universities. Few of the organizers of the educational process consider whether and to what extent new criteria for measuring the efficiency and effectiveness of education help to improve it's quality. But the mission of the university must not be forgotten in the pursuit of the rating. The reduction of the ratio of teachers to students should be proportional and never should compromise the quality of education. Economists regarding education as a form of production, indicate that productivity increases in every sphere except one: the educational sphere. What ways of increasing the productivity of education economists suggest? In addition to staff reductions the period of training is being considerably shortened. For example, four years of studies instead of five years. The use of online courses is another means of improving the effectiveness of education [24: 125-139]. Probably that's the basic threat for education. Even before the opening of radio and television, some attempts were made to organize open education, but all of them turned out ineffective because of the lack of feedback. Interactive online courses use tools to monitor and evaluate the level of learning. Of course, this is not to deny that students can access online courses prepared by leading experts whenever and wherever they have an internet connection. Such a strategy helps to ensure equal opportunities and equal access to education, i.e. to eliminate the distinction between prestigious and other universities [9]. But, put into practice, it could result in increase in demand for certain celebrities, i. e. prominent scientists and specialists, teaching expensive master classes, mainly on TV, while teachers who transfer knowledge and skills, so to speak, "from hand to hand" will be unclaimed.

The University has to train the professionals of tomorrow, the next generation of specialists who will be able to display statesmanship and to make responsible decisions. Therefore, students should be trained not only 
вОЛКовA С. В., MAPKOB Б. В. EDUCATION DILEMMAS IN THE DIGITAL ERA: PHILOSOPHICAL APPROACH // Studia Humanitatis Borealis. 2020. № 3. C. 9-16.

to take tests and written exams, but also to think [1: 1-10].Whereas previously the socially elite was raised at the universities, now many students come to universities not for knowledge, but for diplomas. Teachers train to a standardized test. That's good for memorizing of facts, but it doesn't develop the habits of independent thinking. A student should not only know, but also understand. Meanwhile, the test questions are extremely functional and focused on quantified data. It's easy to answer when you know how many duels Pushkin fought, but there is no quantified answer to the question what is the duel and what role it played in society. Lectures should encourage critical thinking, they should be both problematic and creative, i.e. apart from a critical review assist in finding a solution to the problem. The old system of testing was rigid. The examination was a serious conversation about science problems and required a great effort. On the other hands, such moments were remembered for the entire life.

According to the humanitarian community, it is the new media and interactive educational programs are the main reasons for the deteriorating quality of education. Whereas pupils and students stop reading books and listening to author's lectures, the collapse of education is inevitable. Textbooks turn into comics and lectures into presentations. Now the word "videot" has been used to mean screen students. The stupefying effect of video culture is also evidenced by the fact that spectacles rather bestialize than humanize children. Telling horror stories shouldn't be used as a means of intimidation. We believe, instead, that before any practical changes, it is worthwhile to philosophize about what kind of education, what kind of universities and, most importantly, what kind of educational technologies to be used today.

In our opinion, there are several actual problems in the field of philosophical reflection concerning the phenomenon of education in the digital age.

Firstly, to reflect on crisis in education, as well as the possibilities of renewal of meaningful learning practices, based on personal understanding of the student and the teacher.

Secondly, to overcome the subjective-objective dichotomy and turn to the structures of interpersonal communication as the foundation of educational practice.

Thirdly, to undertake a philosophical and anthropological analysis of human feelings and moods (trust, care, friendship, love) determining the pedagogical atmosphere.

Forthly, to describe electronic mediums as a means of organizing modern educational spaces, as well as a means of electronic disciplinary control, evoking educational subjects' resistance.

Fifthly, to reconstruct the demands the electronic educational technologies are making on the subjects of the educational process. Since these technologies lead to the loss of reflexive experience and form a "clip consciousness", they will need to be supplemented by hermeneutic techniques that contribute to understanding the meaning of education.

And, sixthly, to develop effectively the communicative skills that reduce the risk of social conflict. Since the new media open up opportunities for the development of students' visual and emotional capacities, they also block lively interpersonal communication [22].

The objectives of the study also dictate the following: to provide a philosophical reflection on the nature of cultural and socio-economic transformations that have a substantial impact on education and society in the age of digital technology.

\section{Methods}

Tackling the wider picture, addressing philosophical, cultural, economic aspects of education in digital age, the study offers to make sense what happens and what doesn't happen, when the digital and educational come together.

\section{Results and Discussions}

\subsection{Quality of Education Under Digital Economy}

Reproducing and taking care of their offsprings comprise the most viable strategy for survival and well-being in both nature and society. Education is quite an expensive tool for preserving and transferring cultural heritage. Today, even the universities of the leading world economies complain about suffering from financial shortages, as governments cannot support them at the taxpayers' expense, because tax increases will lead to popular frustration. Commercialization of education by turning existing state universities into service-rendering enterprises and establishing new private universities significantly narrows down the applicants and enhances inequality. What is left is the economic strategy aimed at increasing the number of students and decreasing the number of teachers. New types of media offer a lot of opportunities for achieving such «cost-effectiveness». First, online education can be made available to a large number of people with relatively low income, and second, it enables to cut down the staff. Cost-effectiveness is also reached by reducing time spent on education, for example, by transition to a two-level education system with four-or even three-year bachelor's degree programs [2: 2-9]. The main objection against such approach is raised by the 
вОЛКОвA С. В., MAPKOB Б. В. EDUCATION DILEMMAS IN THE DIGITAL ERA: PHILOSOPHICAL APPROACH // Studia Humanitatis Borealis. 2020. № 3. C. 9-16.

doubts about adequate education quality [23]. Another counter-argument is that efficiency and cost-effectiveness should be discussed in a broader context, taking into account the fact that education is an integral part of social capital, which ensures international competitiveness [15; 4]. That is why cost savings in education lead to the development gap and the loss of international influence. All this suggests that education management based on online technology is not a panacea that will solve all the problems. Intellectual or, in a broader sense, symbolic capital is not governed by the laws of market economy, since it is produced by one individual and consumed by many.

The need for education reform is determined by national governments' inability to bear the financial burden of public education. Back in the day, sciences and humanities were seen not only as the origins of the Industrial Revolution, but also as means of creating national elites, and the symbols of states' political power. It was clear that history, philology, literary studies, and philosophy played a critical part in forming national identity and developing patriotism. However, the role of philosophy in the modern education system is quite ambiguous. If it is perceived as ideology, then the "end-of-ideology epoch" simply does not need it. But in view of the pluralism of ideologies philosophy can be very useful for ideological criticism and analysis.

In the pursuit of new technology we should not abandon traditions, because they help to identify what should be kept intact despite all the modernization processes. In practice, online courses are designed and implemented not according to the principles of liberal education, but with the use of so-called "administrative leverage". In such cases a pre-chosen course is imposed from above and recommended as a teaching model, which does not give an individual teacher any opportunity for self-realization. We need to break this pattern and make sure that course curricula include options that will enable teachers to express their creativity and identity. In this case, lessons will provide more encouragement and academic freedom.

An attempt to approach education reforms from the perspective of "cost-effectiveness" can be explained by more than just financial problems. Since qualitative methods are largely subjective, in practice education quality is assessed with quantitative indicators. In terms of operational efficiency, universities cannot compete with assembly line production, which make it possible to increase output and decrease the number of workers. Is there any solution to this problem? The answer may reside in developing online courses, aiming at several targets at once. First, it will enable to reduce the number of teachers; second, it will ease students' academic load; third, it will improve the availability of university courses; and finally, it will enhance academic mobility. Negative consequences of this approach include averaging and homogenization. Quantitative indicators include the degree of infrastructure development and comfort level, which have no direct effect on teaching quality, but raise the costs of education significantly. Competition for rankings forces many universities with low endowment to save money at the expense of their education services quality.

Thus, education efficiency and cost-effectiveness are two main concerns of education managers. On the one hand, about half of university graduates do not work in the chosen specialty, which means that the education system is running idle. On the other hand, people with high education remain the key driving force of society. That is why we cannot cut expenses simply by reducing the number of universities. This conflict of interests should be discussed with all the stakeholders in mind - tax payers, students and their parents, government officials, and employers. They all have equal rights. So, there is a need to search for compromises, which will be possible if we find a way to make adequate concessions to find a middle ground for all the conflicting sides.

The wants and needs of teachers and students are more or less clear. First, they want lessons to be interesting and useful both for their personal and professional development. Second, they want universities to be packed with more staff and more learners. Finally, both students and teachers want more money and more comfort. Quite understandably, the government in turn wants to make education more cost-effective while maintaining its quality and accessibility. However, if you think about it, no one is going to play random fragments of symphony to the audience of a classical concern. Then why is it deemed possible to substitute some sort of comic strips for full-fledged lectures and textbooks? In order to find the right answers in the era of digital technology, we will need to combine new media with the traditional educational practices of the book culture epoch.

\subsection{Teacher in a world of transition to a digital society}

Modernization of education can be thought of as an addition or replacement of traditional "meaningful" learning practices with new interactive learning programs. Today, education is significantly different from the classical one, which was based on humanities and, above all, philosophy [12: 47-77]. Its principal subject was a teacher. The result depended on their knowledge and talent of teaching. After all, education is not only about acquisition of information, but also about transformation of a student. An existential encounter with the teacher radically changes student's life. However, in order to give advice on emerging problems, teacher must be in 
вОЛКОвA С. В., MAPKOB Б. В. EDUCATION DILEMMAS IN THE DIGITAL ERA: PHILOSOPHICAL APPROACH // Studia Humanitatis Borealis. 2020. № 3. C. 9-16.

constant contact with the student, and conversation should not be reduced to testing.

In his work "On The Future of Our Educational Institutions" F. Nietzsche called for returning from the professor, as a state mouthpiece, to the teacher, as a leader, who forms and improves the human nature. Unfortunately, today teacher in this higher sense seems to be the last romantic in the university that now functions as an educational service enterprise. A kind of reminiscence to the Greek "paideia" is "care of the self" reconstructed in the works of M. Foucault and P. Hadot. Lecturing has ceased to be the basis of learning, and as a result, there is no need in talented lecturers who inspire students to solve fundamental problems of social importance. Wikipedia makes lecturing an unclaimed service.

Many thinkers, writers, and artists in Europe and in Russia understood the task of education wider and deeper than politicians. For instance, Wagner, who conceived a project of a national theatre that aimed to change people spiritually. Nietzsche, though at odds with Wagner, continued his project by other means. His "Zarathustra" was conceived as a new gospel, rejecting the morality of ressentiment, or resentment. Many figures of national culture considered it their task to change the world through books, theatre, music, painting and cinema. They accepted the revolution because they wanted to continue a political upheaval by re-educating body and soul, which they understood to be a backbone of the old system. Unfortunately, bureaucracy did not perceive the people's initiative and suppressed it in every possible way. Liberal democracy also reassures the left-wing intellectuals that stay in the forefront of the ideology of protest movements and revolutions. Its task is seen in production of knowledge and other cultural values, which are regarded as a commodity. If we take into account new social technologies, then we need to consider that unity today is provided not by literature and art, but by media. In place of aesthetes, artists and critics come art and cultural managers. Manipulating numbers, charts, ratings, finances becomes more important and more highly paid than the ability to create works of art. Art's claims to authenticity become ridiculous in face of cynical economic demands and excessiveness of public preferences. Consumerist approach to culture led to the development of art industry and show business. In fact, the purpose of culture is to be a symbolic immune system for both human and society, and not to serve a mere entertainment [10: 172-196].

Education community see digital society as something heartless and formal. These critics have pointed towards the reduction of teaching and learning within national policy-making to matters of 'delivery', with the role of the teacher reduced simply to one of delivering the means with which to digitally learn and, conversely, the role of the student often reduced to one of passive consumer of tightly defined, controlled and bounded forms of official curricular 'knowledge' [17: 33]. It is displacement of quality by quantity, victory of number over letter. It is domination of bureaucracy and technocracy. In response, arguments are made against moralization and humanization. Morality and human rights often lie in source of a protest. Balancing these one-sided assessments, we can assume that society is a complex system that does not obey human aspirations. Since history is "pragmatical", i.e., events depend on goals and values, it is necessary to reconstruct the ways of connection between human and technology.

Modern high culture is experiencing a global crisis caused by the change of mediums. This is, firstly, a twilight of book era, caused by new electronic and computer technologies and, secondly, a crisis of humanism generally and of classical education in particular. Following the post-industrial today, we step into information and digital society. New computer technologies make it possible to radically modernize an education process, and these opportunities are being implemented before our eyes. Schoolchildren and students are reading less books and getting more information on the Internet.

Digitalization is an inevitable, natural stage of knowledge development [14: 178]. There is so much information that it is easier to rediscover than to find it. Of course, a good bibliographer can find literature on topic better than a search engine, and a text translated by a qualified human translator is better than machine translation. The Internet is like a giant dump, in which it is impossible to find something really important. Information is a junk. Unfortunately, $90 \%$ of the books stored in libraries are not used either. On scientific councils we still can distinguish good dissertations from bad ones, but it is not clear what criteria guides a machine when it selects information. It seems to have no distinction of important and unimportant, or even true and false.

Obviously, erudition of a professor is inferior to the Internet. Today, there is so much information that no one can keep it "in mind", so there are no universal scientists. Hence the creation of automatical proccessors, translators, search engines. There is a project to create a "theory of everything" that can be built with this kind of machines. Digital technologies cause a negative reaction among humanities scholars. They indicate that in such a way we lose understanding, creativity and other higher human abilities. This caused a surge of research interest to the techniques and practices of classical education [6]. Without excluding the need to preserve them, it is worth looking at digitalization positively and using digital and computer technologies for the benefit of 
вОЛКОвA С. В., MAPKOB Б. В. EDUCATION DILEMMAS IN THE DIGITAL ERA: PHILOSOPHICAL APPROACH // Studia Humanitatis Borealis. 2020. № 3. C. 9-16.

human. It is obvious that they open up opportunities for education of the masses. Screen culture does not necessarily lead to new barbarism, it opens wide access to world culture and thus promotes humanization, not savagery of the people.

Information society is a new stage of technological development, which affects not only the means of communication, but is also accompanied by profound anthropological and social transformations. It is impossible to understand how modern media works by methods that have developed on the basis of book culture [20: 166]. New techniques of educational process form not only thinking, but also emotional, volitional, valuable acts of consciousness and even psychosomatic states. It is not only video technology and neuro-linguistic programming, but also all sorts of drugs that suppress some and stimulate other affects and abilities of the students. Education involves an ordinary, healthy student. Meanwhile, there are a large number of people with disabilities. They can be included in the education process thanks to digital technologies. Successes of pharmacology allow to cope with mental problems, for example, with increased affectivity, or aggressiveness. In perspective, it is possible to obtain drugs that improve memory and even creativity.

Neuroscience seeks to control brain activity, which, according to cognitive scientists, determines what humanities scholars call thinking. Returning to the meaningful practices of understanding is not considered to be justified. In fact, these euphoric speeches are not confirmed. Brain signaling activity controls, so to speak, lower reactions, and understanding of meaning is a creative ability [19:91-112]. Gene technologies will allow to get rid, for example, of a gene of egoism if it, of course, exists. But even in this case we are not talking about development of traditional pedagogy. On the contrary, new problems will arise. If there are genes for language, intelligence, creativity, freedom, then all these can be controlled. So, it turns these qualities into the opposite. Therefore, genetic engineering is not safe. However, all discoveries meet such problems, and this is not a fault of science and technology, but of the cave thinking of those people who use scientific discoveries to achieve their selfish goals.

New discoveries in cognitive sciences have upended conventional notions about the process of acquiring and transmitting knowledge. Genetic engineering and a fantastic project to re-construct a person make you think about the consequences. As long as they promise to improve people's cognitive abilities, there is no doubt. A new trend - that is protection of animal rights - allows you to predict a project of breeding intelligent non-human animals, i.e. animals with a human-like brain [7]. If intelligent animals, for example, are bred for the needs of production or for humane reasons, then there is a problem of training them. Intelligent animals can and should be educated. Since the task of philosophy is to predict a nature of the future revolution in education, it is worth imagining what it could be [21]. This depends on what breed and for what purposes we seek to receive. The slave was a talking thing, a property of a master and had no rights. And if animals have soul, then the situation changes. Nevertheless, it cannot be ruled out that in pursuit of cheap labor capitalism will use them in its own way. If an animal replaces proletariat, will it not become a subject of world spirit, i.e. of history?

Success of new gene technologies, work on creation of artificial intelligence mean stepping into posthuman, posthumanistic phase of human development [16 : 95]. Human is a product not only of nature, but also of technology With the development of civilization - artificial and technical, social and symbolic reality - we have heard fears about the loss of morality (Rousseau), alienation from the generic essence of human (Marx), the "forgetfulness of Being" (Heidegger). Today we are talking about a new, unheard-of threat. New digital technologies discard previous ideas about human qualities [5].

Recognizing the shortcomings of both human nature and social organism, however, it is necessary to check the consequences of posthumanism. What are we afraid of? Intelligence can be developed on an inorganic basis, replacing the body with prostheses, though frightening painful operations, but forever eliminates diseases. As for emotional experiences, perhaps it would be better if some of them did not exist. It is enough to read novels so that to be horrified by the perversity of human feelings. Advances in new gene technologies provide a chance to get rid of a number of painful experiences, phobias, phantasms, which infected the human consciousness, responding to violence from society with more dangerous perversions. One-sided development of culture generates many negative consequences. Society is filled with unsatisfied desires, envy, thirst for revenge.

The task of intellectuals is to develop and offer to society such technologies of education and humanization of people that would make unnecessary ways of manipulating people practiced in the modern "managed society". According to G. Lipovetsky, modern society is moving away from insouciance of postmodernism [8]. He noted decline in employment, rising unemployment, decline of education. At the same time, in the halo of anxiety, consumer fever only intensifies. Young people choose profession taking into account the future needs of labor market, hence the continuity of education and retraining. Marriages are becoming longer, investments in children are increasing. People from their youth are concerned about the 
вОЛКовA С. В., MAPKOB Б. В. EDUCATION DILEMMAS IN THE DIGITAL ERA: PHILOSOPHICAL APPROACH // Studia Humanitatis Borealis. 2020. № 3. C. 9-16.

future pension. Health care becomes an obsession. Prevention, medical examination, early detection of diseases are aimed at reducing risks and increasing life expectancy. All this suggests that future is becoming very relevant for our contemporaries. People no longer live in one day, modern individualism is burdened and limited by temporality. If earlier companies regulated only working hours, now leisure time has also received economic value. While class contradictions decrease, existential tension is growing. There are more problems and less time to solve them. Hence the constant stress, fatigue, mental disorders. Laziness, carelessness, entertainment are in the past. Discipline, organization, responsibility have replaced them.

According to P. Sloterdijk, restoring warm and close relationships between people can save society [18]. On the contrary, according to N. Luhmann, functional relationships connect people much stronger than personal relationships [11]. The latter cannot be a mainstay of large superhuman state machines at all. They form family organisms and small moral and spiritual communities based on friendship and trust. At the same time, society, as a viable superorganism, is not a result of violence or bureaucratic organization, but grows on the basis of human competencies, which are the most important factor of socialization. Trust and justice, as J. Habermas argued, suggest the formation of a free public that controls the work of institutions from economic to political [3]. A. Papakostas wrote an interesting work that shows how problems, usually related to the department of morality, are effectively solved through social organization [13].

Social reality resembles a city where modern skyscrapers coexist with ancient buildings. New forms of life sooner or later transform and subdue traditional ways, but the new does not become total, because there are always territories not covered by capitalism. If we should suggest tactics of modern social transformations, we could advise to fight for expansion of such territories, not to concede them to market and commerce. The true way to be is to fight for the preservation of human relationships.

\section{Conclusion}

Although there is a great number of philosophical programs, as well as specific educational methods and techniques, a methodical analysis in the philosophy of education is still massively under-represented. There is a need to escape striking differences between spirit and nature, subject and object, body and spirit, human and animal to correctly address the education issue. Although all these differences as a basis of our language cannot be fully eliminated, yet it does not exclude the different ways of applying them in a particular situation. Thinkers who claimed the death of Man, Subject, Truth, and other significant notions, are unpopular today, since the new theories reveal the old repressive notions. We should probably live in harmony with nature as well as in harmony with techniques. Digitalization saves us the trouble of tedious work and leaves more space for creativity. It is necessary to realize what machines and computer programs can and cannot do. Hence, the recommendation resulting from our reasoning is to reform education so as not to waste time studying what machines can do, but to teach how to use them for human purposes.

\section{References}

1. Athreya B. H., Mouza, C. Thinking Skills for the Digital Generation. Switzerland, 2017. 179 p. DOI: 10.1007/978-3-319-12364-6

2. Bowen W. G. Higher Education in the Digital Age. Princetone, 2013. 192 p.

3. Habermas J. Structural change in the public sphere. Studies on the category of bourgeois society. Moscow, 2016. 344 p. (In Russ.)

4. Imandoust S. B. Relationship between Education and Social Capital. In International Journal of Humanities and Social Science, 2011. № 1 (12). P. 52-57. (In Russ.)

5. Knox J. Posthumanism and the MOOC: opening the subject of digital education. In Studies in Philosophy of Education. 2016. № 35 (3). P. 305-320. DOI:10.1007/s11217-016-9516-5

6. Kositsky N. Synergy Between Digital and Traditional Literacy Practices: A Framework for Building a Reading Culture in a Secondary School: Doctoral Dissertations / University of Massachusetts Amherst, 2016. 174 p.

7. Kozhevnikova M. Hybrids and chimeras of man and animal: from mythology to biotechnology. Moscow, 2017. 151 p. (In Russ.)

8. Lipovetsky G. The Future of Philosophy: Professional and Institutional Aspects. St. Petersburg, 2011. P. 248-289. (In Russ.)

9. Littlejohn A., Hood N. Reconceptualising learning in the digital age. The [Un]democratizing potential of MOOCs. Springer Singapore, 2018. 108 p. DOI: 10.1007/978-981-10-8893-3

10. Markov B. Being Human in the Modern World / St. Petersburg, Filologicheskij fakul'tet SPbGU, 2013. 
вОЛКОвA С. В., MAPKOB Б. В. EDUCATION DILEMMAS IN THE DIGITAL ERA: PHILOSOPHICAL APPROACH // Studia Humanitatis Borealis. 2020. № 3. C. 9-16.

\section{2 p. (In Russ.)}

11. Luhmann N. Self-Descriptions. Moscow, 2009. 320 p. (In Russ.)

12. Nussbaum M. Not for Profit: Why Democracy Needs the Humanities. Princeton, NJ, 2010. 158 p.

13. Papakostas A. Formation of a civilized public sphere: distrust, trust and corruption. Moscow, 2016. 224 p. (In Russ.)

14. Peters M. A., Jandrić P. Philosophy of education in the age of digital reason. Review of Contemporary Philosophy, 2015. № 14. P. 162-181.

15. Plagens G. Social Capital and Education: Implications for Student and School Performance. Education \& Culture, 2011. № 27 (1). P. 40-64.

16. Pötzsch H., Hayles K. Posthumanism, technogenesis, and digital technologies: A conversation with N. Katherine Hayles. The Fibreculture Journal. 2014. № 23. P. 95-107.

17. Selwin N. Schools and Schooling in the Digital Age. A Critical Analysis. London\&New-York, 2010. 194

p.

18. Sloterdijk P., Heinrichs H.-J. Sun and death: Dialogical research. St. Petersburg, 2015. 450 p. (In Russ.)

19. Smirnova N. M., Demchenko L. M. Creativity as a process of creating meanings. In Creativity: an epistemological analysis. Moscow, 2011. P. 91-112. (In Russ.)

20. Sokolova N. L. Popular culture web 2.0: to cartography of the modern media landscape. Samara, 2009. 166 p. (In Russ.)

21. Timofeeva O. History of animals. Moscow, 2017. 208 p. (In Russ.)

22. Volkova S. Homo educandus's search for meaning. Petrozavodsk, 2019. 248 p. (In Russ.)

23. Young Sh. From Disruption to Innovation: Thoughts on the Future of MOOCs. Educational Studies. 2018, № 4. P. 21-43. DOI: 10.17323/1814-9545-2018-4-21-43

24. Zawacki-Richter, O., Qayyum, A. The state of open and distance education. Open and distance education in Asia, Africa and the middle east. National perspectives in a digital age. Singapore, 2019. P. 125-140. DOI: 10.1007/978-981-13-5787-9

Received: 24.11 .2020 


\section{EDUCATION DILEMMAS IN THE DIGITAL ERA: PHILOSOPHICAL APPROACH}

\section{VOLKOVA \\ SVETLANA}

\section{MARKOV BORIS}

\author{
Keywords: \\ Keywords: philosophy \\ education \\ digitalisation \\ online courses \\ tests \\ education policy \\ quality of education Keywords: \\ philosophy of education \\ human being \\ online courses \\ digital economy \\ education outcomes
}

Doctor of Philosophy, Associate Professor, Petrozavodsk State University, Department of Philosophy and Cultural Studies,

Petrozavodsk, Russian Federation, svetavolkov@ya.ru

Doctor of Philosophy,

Professor,

St. Petersburg State University, Institute of Philosophy, Department of Philosophic Anthropology,

St. Petersburg, Russian Federation, bmarkov@mail.ru

\section{Summary:}

The article presents philosophical and critical exploration of education in the framework of intensive informatization of modern society. The use of digital technology is nowadays a key feature of educational practices in the world. Yet despite its prominence, digital technologies in education continue to be an issue that rarely receives sustained critical attention and thought. Tackling the wider picture, addressing philosophical, cultural, economic aspects of education in digital age, the study offers to make sense what happens and what doesn't happen, when the digital and educational come together. Both positive and negative consequences of the spread of e-learning systems and technologies are analyzed. Examining contemporary education in terms of social justice, equality and meaningfulness the authors formulate the key tasks facing the philosophy of education in the modern digital era. The authors conclude that it is necessary to supplement electronic educational technologies with traditional educational practices. In particular they examine the trends and prospects of cognitive research and biotechnologies in the light of their influence on the human ideal that characterizes contemporary education. The authors argue that a serious and fruitful comprehension of education in the digital age requires a revision of the classic opposition of the subject and object, spirit and body, man and animal. 